\title{
INTERPRETATION OF THE CHEMICAL AND PHYSICAL TIME-SERIES RETRIEVED FROM SENTIK GLACIER, LADAKH HIMALAYA, INDIA
}

\author{
By Paul A. Mayewski, W. Berry Lyons, \\ (Department of Earth Sciences, Glacier Research Group, University of New Hampshire, Durham, New Hampshire 03824, U.S.A.) \\ N. Ahmad, \\ (Aligarh Muslim University, Aligarh, India) \\ Gordon SMITH, \\ (Department of Earth Sciences, University of New Hampshire, Durham, New Hampshire 03824, U.S.A.) \\ and $\mathrm{M}$. POurchet \\ (Laboratoire de Glaciologie du CNRS, Grenoble, France)
}

\begin{abstract}
Spectral analysis of time series of a $c .17 \pm 0.3$ year core, calibrated for total $\beta$ activity recovered from Sentik Glacier $(4908 \mathrm{~m})$ Ladakh, Himalaya, yields several recognizable periodicities including subannual, annual, and multi-annual. The time-series, include both chemical data (chloride, sodium, reactive iron, reactive silicate, reactive phosphate, ammonium, $\delta \mathrm{D}, \delta\left({ }^{18} \mathrm{O}\right)$ and $\mathrm{pH}$ ) and physical data (density, debris and ice-band locations, and microparticles in size grades 0.50 to $12.70 \mu \mathrm{m}$ ). Source areas for chemical species investigated and general air-mass circulation defined from chemical and physical time-series are discussed to demonstrate the potential of such studies in the development of paleometeorological data sets from remote high-alpine glacierized sites such as the Himalaya.

RÉsumÉ. Interprétation des séries de variations chimiques el physiques reconstituées au Sentik Glacier, Ladakh Himalaya, Inde. L'analyse spectrale de l'activité $\beta$ totale d'une série temporelle de glace $17 \pm 0.3$ a issue du Sentik Glacier (4908 m) Ladakh Himalaya, a permis de reconnaître, plusieurs périodicités, subannuelles, annuelles et multi-annuelles. Cette série comprend à la fois des résultats chimiques (chlorures, sodium, fer actif, silicate actif, phosphate actif, ammonium, $\delta \mathrm{D}, \delta\left({ }^{18} \mathrm{O}\right)$ et $\left.\mathrm{pH}\right)$ et de données physiques (densité, localisation des bandes de glace et de sédiments et microparticules dans les
\end{abstract}

\section{IN TRODUCTION}

Advances in climate prediction depend on a knowledge of historical and climatic sequences ranging in scale from seasons to millennia. Proxy data provided by glaciers can be used to construct these sequences when direct observations of the atmosphere are either spatially or temporally lacking. The glaciers of high Asia provide a unique tool for retrieving proxy data concerning atmospheric circulation because of their geography and elevation. Yet, although these glaciers comprise by area $50 \%$ of all glaciers outside of the polar regions and contain approximately 33 times the areal cover of the glaciers in the European Alps (Wissman, 1960) they are perhaps the least understood and least intensely studied glacier system in the world.

The importance of glaciers as proxy indicators of climate in Asia is substantiated when one considers that the monsoonal circulation system that interacts with these glaciers is of great concern for the socioeconomic stability of the Indian subcontinent.

Mukherjee and other (1981) estimate that approximately $75-90 \%$ of the annual rainfall reaching the Indian subcontinent comes during the summer monsoon and Bahadur (personal communication in 1982) suggests that as much as $25-40 \%$ of the runoff in India could come from melting glaciers. Furthermore, the Asian monsoon circulation system may even have links to the severity of snow cover over Eurasia (Hahn and Shukla, 1976) which may in turn interact through the jet stream to exert influence on the weather and climate of North plages de dimension de 0,50 à $12,70 \mu \mathrm{m})$. On discute les zones sources pour les espèces chimiques trouvées et la circulation générale des masses d'air impliquée par les sérics chimiques et physiques inventoriées, on montre les possibilités de ce type d'étude pour le développement des connaissances paléométéorologiques dans les sites de haute montagne alpine englacée tels que l'Himalaya.

Zusammenfassung. Interpretation einer chemischen und physikalischen Zeitreihe, gewonnen am Sentik-Gletscher, Ladakh-Himalaya, Indien. Die Spektralanalyse einer $17 \pm 0.3$ a, mit Gesamt- $\beta$-Aktivität kalibrierten Zeitreihe aus dem Sentik-Gletscher $(4908 \mathrm{~m})$ im Ladakh-Himalaya liefert einige erkennbare Periodizitäten, darunter solche von weniger als einem Jahr Dauer sowie ein- und vieljährige. Die Zeitreihe enthält sowohl chemische (Chlorid, Sodium, aktives Eisen, Silikat und Phosphat, Ammonium, $\delta \mathrm{D}, \delta\left({ }^{18} \mathrm{O}\right)$ und $\mathrm{pH}$ ) wie physikalische Daten (Dichte, Lage von Schutt und Eisbändern sowie Mikropartikel in Grössen von 0.50 bis $12.70 \mu \mathrm{m}$ ). Um die Bedeutung solcher Studien für die Aufstellung paläometeorologischer Datensätze aus vergletscherten Gebieten von Hochgebirgen wie dem Himalaya zu zeigen, werden die Herkunftsgebiete der untersuchten chemischen Stoffe und die allegemeine Luftzirkulation, die sich aus chemischen und physikalischen Zeitreihen ableiten lässt, diskutiert.

America (Reiter, 1981). The Himalayan ice mass also has interhemispheric teleconnections since $75 \%$ of the air mass entering western India comes from the Southern Hemisphere (Rangarajan and Eapen, 1981).

The most direct glacier proxy monitoring of monsoonal circulation is gained by the determination of the net mass balance, source area, and timing of precipitation using time-series derived from chemical and physical studies of ice cores. This paper presents the first of a series of such approaches which stem from prior investigations of Himalayan glacier fluctuation records (Mayewski and Jeschke, 1979) and examination of the feasibility of glaciochemical sampling in the Himalaya (Mayewski and others, 1981).

\section{GEOGRAPHY AND METEOROLOGY OF NUN KUN}

Nun Kun (long. $75^{\circ} 71^{\prime}$ to $76^{\circ} 08^{\prime} E$.; lat. $35^{\circ} 57^{\prime}$ to $35^{\circ} 02^{\prime} \mathrm{N}$., Fig. 1) is commonly used as the name for the rectangular massif $(25 \mathrm{~km} \times 13 \mathrm{~km})$ at the northwestern end of the Zaskar Range in Ladakh, India. It was chosen as a study site because in addition to containing several glaciers that radiate off its central snow-covered plateau it is a relatively arid portion of the Himalaya, close to the northern limit of the summer monsoon and is, therefore, potentially an area sensitive to monsoonal fluctuations.

Meteorological conditions in the Himalaya are dominated by the activity of the monsoonal system. During the winter months air flow in the general region of the study area is approximately north-west 


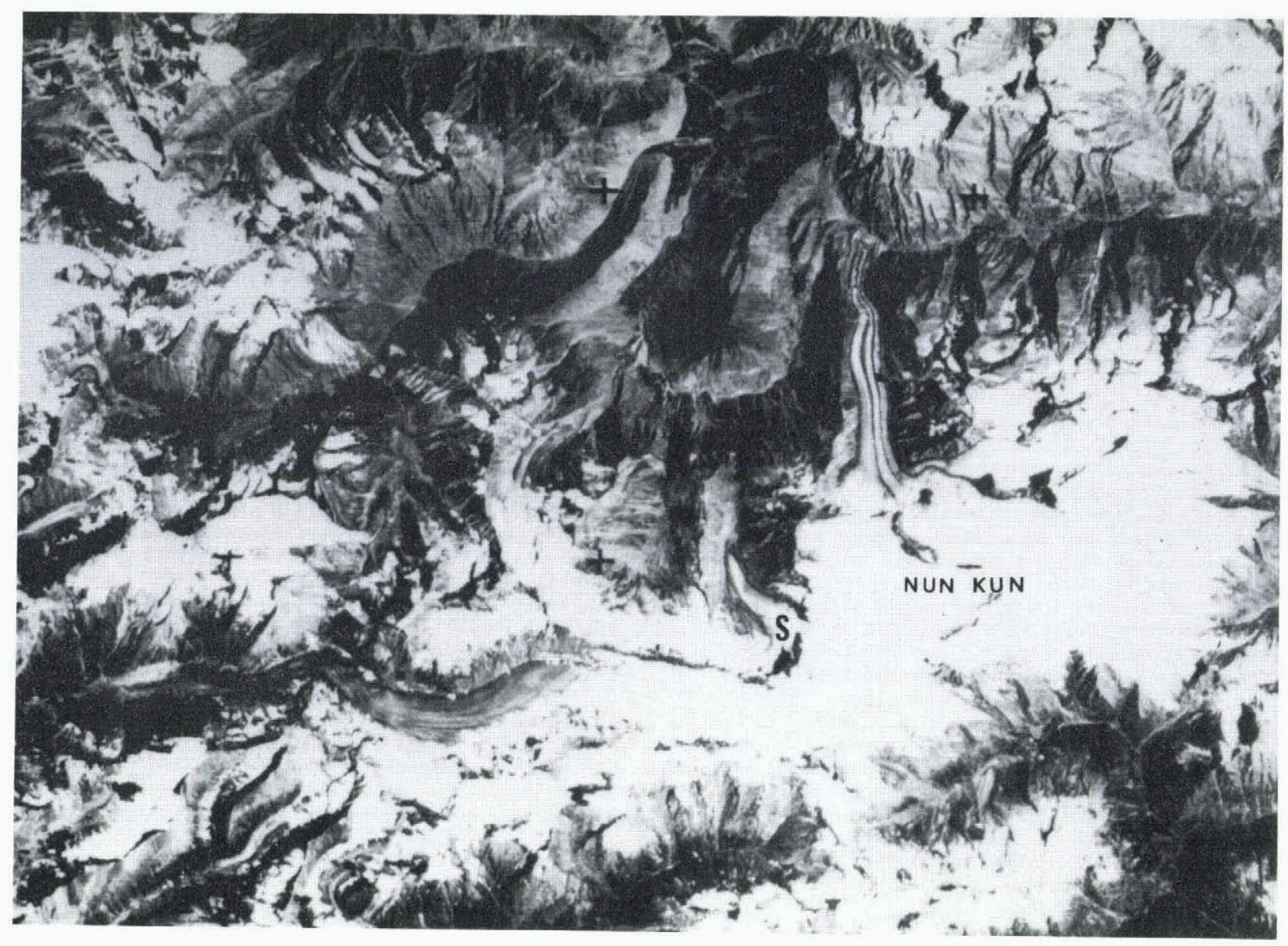

Fig. 1. Location of core site from a portion of NASA Landsat Image E-30531-04491-C displaying the Nun Kun massif in the lower center of the photograph. Peaks in massif center attain elevations as high as $7135 \mathrm{~m}$ (Nun) and $7077 \mathrm{~m}$ (Kun). Glacier with banded moraine flows directly north off the massif. Moraine bands as seen on the photograph are approximately $6 \mathrm{~km}$ in length. The Suru River meanders past the snout of this glacier. $S$ marks the core site $(4908 \mathrm{~m})$ on Sentik Glacier.

to south-east near the ground surface and west to east at the 500 mbar level (Boucher, 1975). Summer air-mass circulation includes south-west to northeast to north-west flow near the ground surface and at the 500 mbar level air flow is eastward along the northern portion of the Himalaya and westward along the southern portion of the range (Boucher, 1975). An anticyclone rests for a portion of the summer season over the Himalaya and divides the eastwardand westward-flowing 500 mbar level air system (Boucher, 1975). The lower air mass is believed to be relatively thin $(<2 \mathrm{~km})$ and overlain by an arid continental air mass (Sequeira and Kelkar, 1978).

Primary maximum precipitation comes to the region of the study site during the period July to August and primary minimum during November (Boucher, 1975). Estimated total rainfall for valley bottoms in the Nun Kun area is $0.90 \mathrm{~m} \mathrm{a}^{-1}$ water equivalent (Qazi, 1973). Rainfall records are available from several stations in the region, however the data are scant and contain numerous inconsistencies. Discharge records for the Suru River (Fig. 1), which flows in the valley directly north of the core site, suggest that the warmest time of the year is June to August (Qazi 1973).

The main core site was chosen at an elevation of $4908 \mathrm{~m}$ on a relatively flat, single-flow portion of a $3 \mathrm{~km}$ long alpine glacier, Sentik Glacier ( $S$ on Fig. 1), that flows north-east off the Nun Kun massif. Several other core sites were investigated in the massif area, at elevations as high as $5512 \mathrm{~m}$, but these were either affected by avalanches or as in the case of the Nun Kun plateau itself primarily composed of wind-blown snow.

Interpretation of down-hole glaciochemistry recovered from the Sentik Glacier core is based on the assumption that neither melting nor percolation, to depths significantly less than seasonal accumulation levels, is present at the core site. Although, as already noted, few meteorological data are available from the region, radiosonde measurements from Srinagar (1700 m a.s.1. $120 \mathrm{~km}$ east of Nun Kun) reveal that even during the warmest months of the year, June-August, at only 500-600 m above Srinagar, mean monthly temperatures barely rise to $0^{\circ} \mathrm{C}$. Furthermore, a set of down-hole temperatures made at the study site in July suggest that although the upper few centimeters of the glacier are close to $0^{\circ} \mathrm{C}$, immediately beneath the surface, temperatures drop until finally at a depth of $9 \mathrm{~m}$ the core attains and maintains temperature of $-3.0^{\circ} \mathrm{C}$ to a depth of at least $16.6 \mathrm{~m}$.

As an additional test for the investigation of melt-water potential, plexiglass trays designed to capture melt water were inserted in snow-pits close to the sample site. Although this monitoring was conducted in late July, close to the peak of the summer season and at several depths $(5,10,20,30,40$ and $50 \mathrm{~cm}$ ) no melt water was found in the trays. The presence of several thin ice bands, comprising $<5 \%$ of the total core, suggests that melt events, although not common, do occur at certain times. Hastenrath (1978) has demonstrated that high-altitude areas, 
such as the summit of Quelccaya ice cap, Peru, may absorb too little net radiation to allow melting. Although we do not have radiation data to compare to Hastenrath's, the same situation may have existed at the Sentik Glacier core site for much of the time period represented by the core.

\section{ME THODOLOGY}

Samples collected from a $16.6 \mathrm{~m}$ core on Sentik Glacier were analyzed for density, microparticles, and chemical properties (chloride, sodium, reactive iron, reactive silicate, reactive phosphate, ammonium, $\delta D, \delta(180)$, total $\beta$-activity, and $\mathrm{pH})$. Although the collection interval was continuous at $8 \mathrm{~cm}$, most analyses were performed at $16 \mathrm{~cm}$ intervals due to sample volume constraints. Extreme care was taken at all times during sample collection, handling, and analyses to prevent sample contamination as required by the nature of the chemical studies. Cores were taken using a manually operated pre-cleaned tefloncoated SIPRE-type auger. Plastic suits, plastic gloves, and particle masks were worn by all members of the party who came in direct contact with the exposed core.

Each sample had its outer 1-2 cm scraped immediately after sectioning from the cores using precleaned plexiglass scrapers, and the scrapings were discarded to reduce possible contamination by the auger. Once scraped, samples were placed in precleaned plastic bags. Pre-cleaning of bags, scrapers, and the auger involved a soap and water wash with rinsing several times in distilled-deionized water. After melting in the plastic bags each sample was transferred to two $30 \mathrm{ml}$ and one $125 \mathrm{ml}$ (LPE) container, pre-cleaned as described above, and one $125 \mathrm{ml}$ (LPE) container that was pre-cleaned by acid- washing in concentrated hydrochloric acid followed by rinsing several times in distilled-deionized water.

The portion of the sample in the soap-and-water cleaned $125 \mathrm{ml}$ container was used for analysis of chloride ( $\mathrm{Za} 11$ and others, 1956) and of reactive phosphate employing AutoAnalyzer techniques (Glibert and Loder, 1977). The portion of each sample in the acid-cleaned $125 \mathrm{ml}$ container was used for analysis of reactive silicate and reactive iron by AutoAnalyzer using the techniques of Glibert and Loder (1977) and Stookey (1970), respectively. These samples were acidified with ultrapure $\mathrm{HNO}_{3}$ and allowed to sit at room temperature for at least two weeks prior to analysis. Sodium was analyzed via atomic absorption spectrophotometry. All of the aforementioned were analyzed at the University of New Hampshire. Duplicate analyses of standards were used to determine the precision of analysis for chloride, reactive iron, reactive silicate, reactive phosphate and sodium. Analytical precision of the replicate analyses of standards was $\pm 1 \%$ at $7.0 \mu \mathrm{M}, \pm 1 \%$ at $4.5 \mu \mathrm{M}, \pm 1 \%$ at $4 \mu \mathrm{M}$, $\pm 4 \%$ at $0.5 \mu \mathrm{M}$, and $\pm 3 \%$ at $13.0 \mu \mathrm{M}$, respectively. The two $30 \mathrm{ml}$ (LPE) containers mentioned previous ly were used for collecting portions of the melted samples that were analyzed for $\delta D, \delta(180)$, and total $\beta$-activity measurements were made in the CNRS Laboratoire de Glaciologie, France, on one set of $30 \mathrm{ml}$ containers that were sealed with wax to prevent diffusion. Volumes required for total $\beta$-activity measurement required lumping of samples. $\mathrm{pH}$ was analyzed in the field on the other set of $30 \mathrm{ml}$ samples using an Orion Ionanalyzer T.M. model $399 \mathrm{~A}$ portable pH meter with an Orion 91-06 combination $\mathrm{pH}$ electrode standardized using NBS buffers of $\mathrm{pH}=4.01$ and $\mathrm{pH}=7.00 . \mathrm{pH}$ analyses were made without stirring. Microparticles were analyzed at The Ohio State University using the $30 \mathrm{ml}$ sample set from $\mathrm{pH}$. The technique employed a Coulter

TABLE I. MEAN VALUES FOR TIME-SERIES SETS IN APPENDIX A

Time-series set

Chloride

Sodium

Reactive iron

Reactive silicate

Reactive phosphate

Ammonium

$\delta D$

$\delta\left({ }^{18} 0\right)$

$\mathrm{pH}$

Total $\beta$-activity

Density
Mean

$2.94 \mu \mathrm{M}$

$3.14 \mu \mathrm{M}$

$13.91 \mu \mathrm{M}$

$8.35 \mu \mathrm{M}$

$0.39 \mu \mathrm{M}$

$1.07 \mu \mathrm{M}$

$-97.90 \%$

$-15.07 \%$

4.12-5.85 pH units*

$224.76 \mathrm{dph} \mathrm{kg}^{-1}$

$570 \mathrm{~kg} \mathrm{~m}^{-3}$ sample number

114

114

228

228

228

114

19

21

209

Microparticles (examples of 3 out of the 15 size grades available appear below)

$0.50-0.63 \mu \mathrm{m}$

$1.00-1.25 \mu \mathrm{m}$

$8.00-10.00 \mu \mathrm{m}$
$34 \times 10^{3} \mu \mathrm{m}$ size particles/500

$\mu l$ of sample

$20 \times 10^{2} \mu \mathrm{m}$ size particles/500

$\mu l$ of sample

$3 \mu \mathrm{m}$ size particles/500 $\mu 1$ of sample
114

* range rather than mean is specified due to the $\log$ scale used to measure $\mathrm{pH}$. 
Counter (L.G. Thompson, 1977) and yielded 15 size grades in the range 0.50 to $12.70 \mu \mathrm{M}$.

\section{DATA ARRAY AND INTERPRETATION}

Time-series sets of down-hole chemical properties (chloride, sodium, reactive iron, reactive silicate, reactive phosphate, $\delta \mathrm{D}, \delta(180), \mathrm{pH}$, and total $\beta$ -

activity) and physical properties (debris and ice band locations, density, and three selected microparticle size grades out of the 15 size grades analyzed) appear in Appendix A. Table I contains a list of mean values for all of the data sets appearing in Appendix $\mathrm{A}$. Results stemming from the analysis of this data array follow.

\section{Core chronology}

Total B-activity measurements although integrated over more than one sample are available for the entire length of the core. The resultant total $\beta$-activity record has a built-in \pm 0.3 error in down-hole position due to the sampling interval required for this analysis. In the depth range 15.40-15.96 m a maximum total $\beta$ activity value for the core was encountered, $639 \mathrm{dph}$ $\mathrm{kg}^{-1}$, which is believed to coincide with the 1963 thermonuclear test level. The time period represented by the core is therefore $\approx 17 \pm 0.3$ years which is equivalent to an average net mass balance of $\approx 0.92 \mathrm{~m} \mathrm{a}^{-1}$. Using an average core density of $570 \mathrm{~kg} \mathrm{~m}^{-3}$ this yields an average net mass balance of $0.62 \mathrm{~m} \mathrm{a}^{-1}$ water equivalent.

\section{Periodic events}

With the exception of total $\beta$-activity, $\delta(180)$, and debris and ice band locations all of the data sets in Appendix A are nearly regularly spaced. The latter yield an array of 23 time series sets each with a value every $0.16 \mathrm{~m}$ down core and some (reactive iron, reactive silicate, and reactive phosphate) with values every $0.08 \mathrm{~m}$ down core. The volume of data and potential combinations presented by these data require synthesis using a statistical technique capable of revealing trends such as periodicity. Spectral analysis involving the computation of spectral density (power) at chosen frequencies provides just such a statistical tool. Power at a given frequency is the measure of how much of the variance of a time-series, or in this case a depth-series exists at a particular frequency
(period).

Power, frequency, period, and confidence interval, at specified frequencies, appear in Figure $2 a-c$. For most of these depth-series several power peaks are recognizable. Reliability of peaks was tested using simplified filtering and by varying lag number in sev-
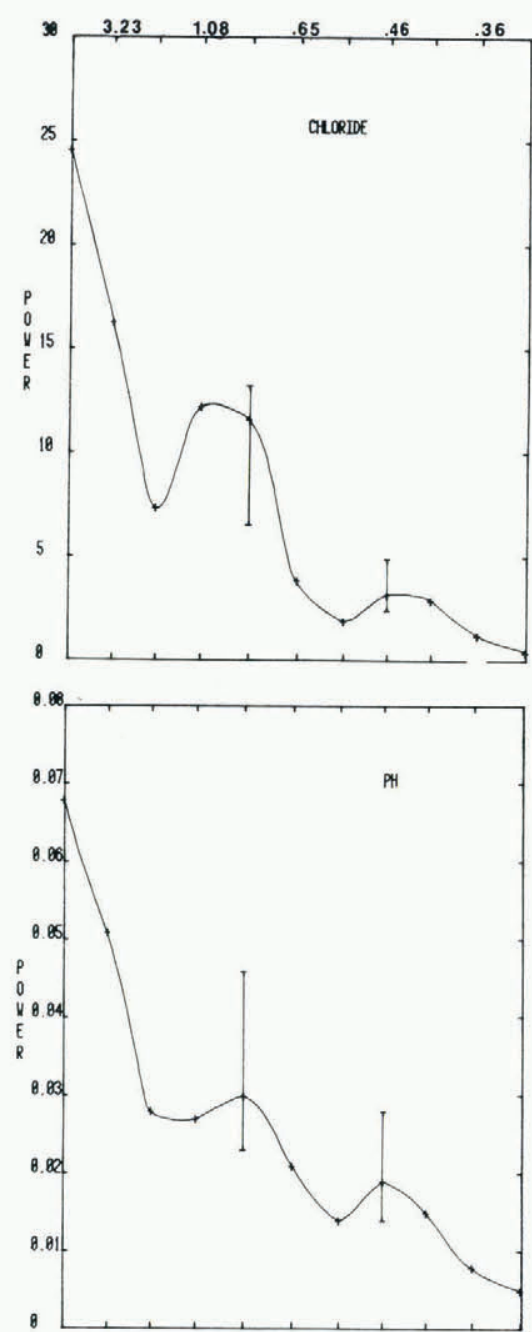

$\begin{array}{lllllllllllll}8 & 8.31 & 8.02 & 8.93 & 1.24 & 1.55 & 1.86 & 2.17 & 2.48 & 2.79 & 3.1\end{array}$
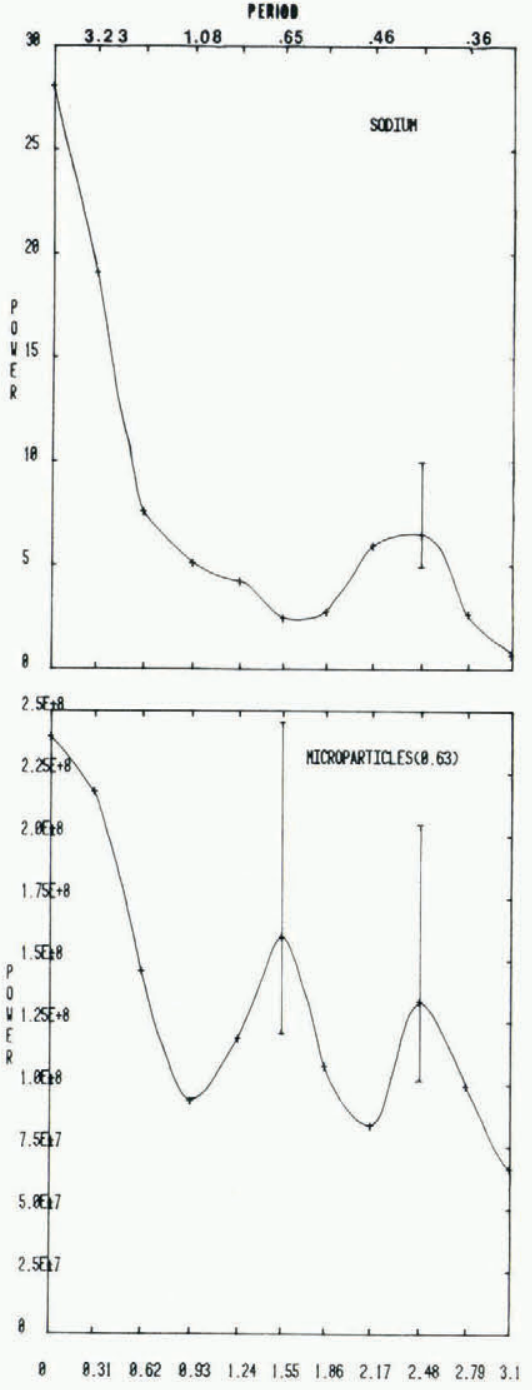

Fratery
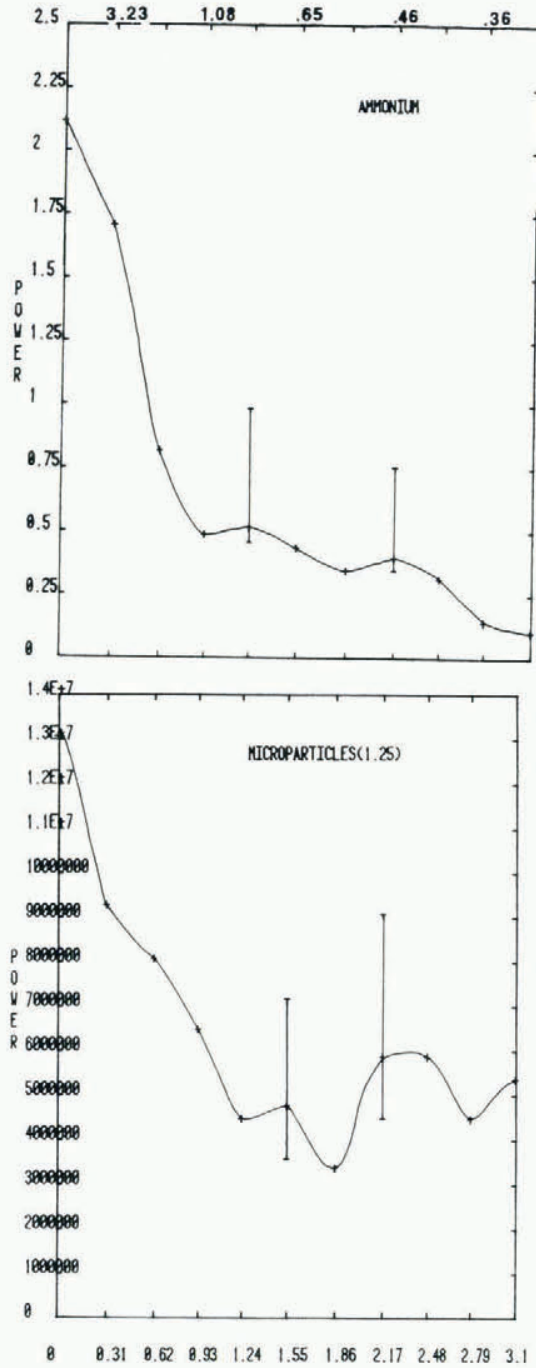

$2 a$ - includes time-series sets displaying annual and subannual power peaks at 10 lags ( $n=114$ ). 

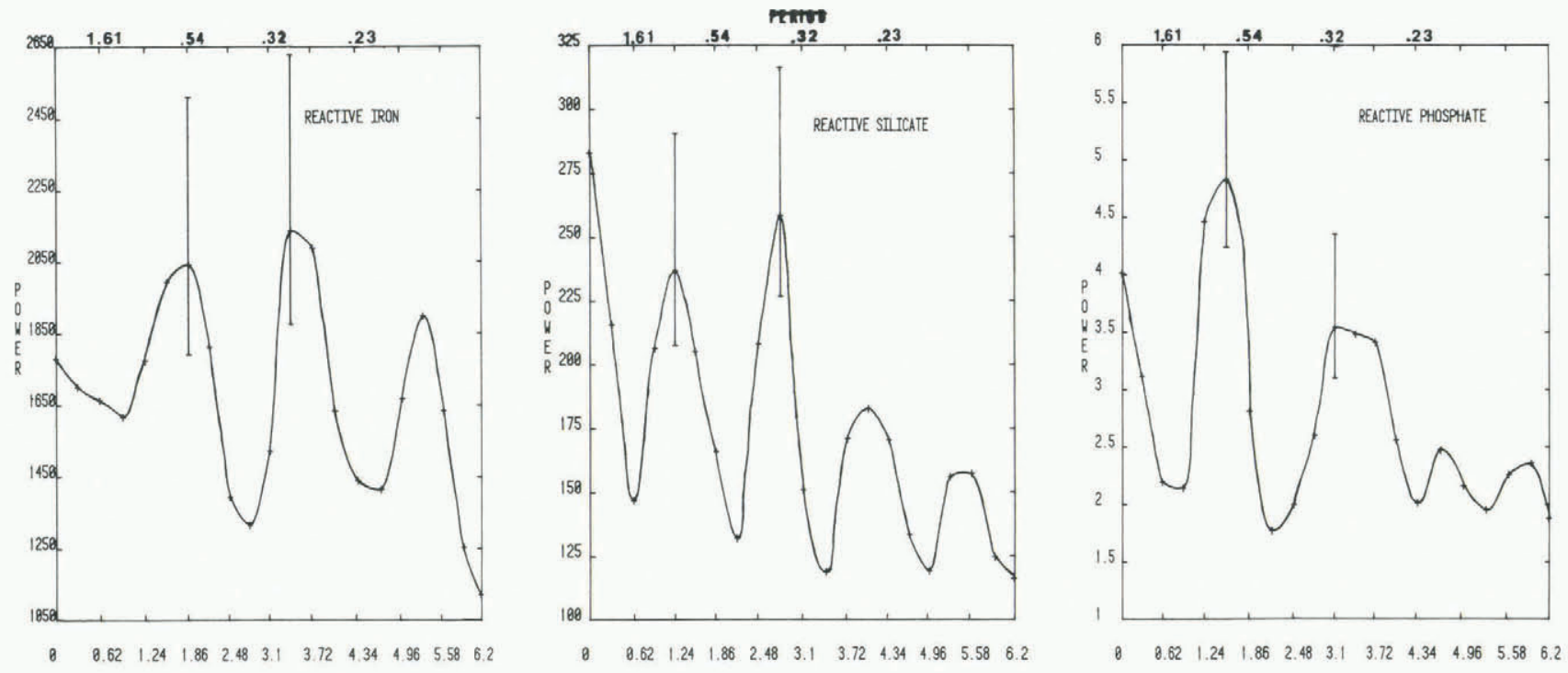

$2 b$ - includes time-series sets displaying annual and subannual power peaks at 20 lags $(n=228)$.
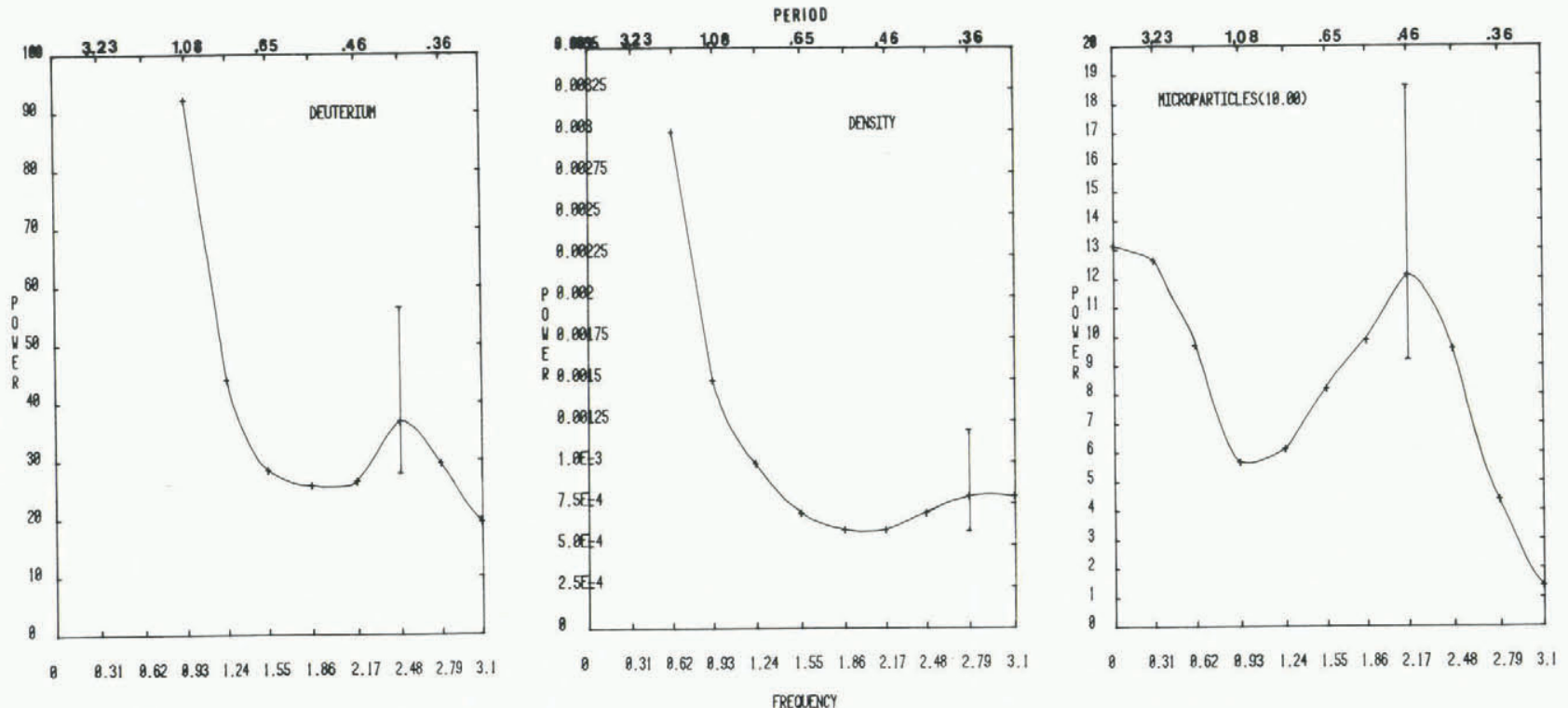

$2 c$ - includes time-series sets at 10 lags displaying just subannual power.

Fig. 2. Power (unit $\left.{ }^{2} / c y m^{-1}\right)$, period $(m)$ and frequency $\left(c y m^{-1}\right)$ for timeseries sets. Units equal to $\mu \mathrm{M}$ for chemical species, $\% / 00$ for $\delta D$, pH units for $\mathrm{pH}, \mathrm{kg} \mathrm{m}^{-3}$ for density and particles/500 $\mathrm{\mu l}$ of sample for specified um microparticle size grades. Vertical bar represents $80 \%$ confidence interval for power peaks at 12 degrees of freedom for $n=114$ and 24 degrees of freedom for $n=228$ (after Koopmans, 1974). The lower limit of the vertical bar defines whether the peak departs significantly enough from baseline to the classified as a peak. Note that confidence interval is valid only at frequency (period) specified. Confidence interval for period $= \pm 0.16 \mathrm{~m}$ using a 20 sampling interval.

eral runs. These peaks occur at periodicities of: $\geqslant 3.22 \mathrm{~m},<3.22$ to $>0.32 \mathrm{~m}$ and $\leqslant 0.32 \mathrm{~m}$. Using the chronology provided by the total $\beta$-activity measurements and the resultant average net mass balance, $0.92 \mathrm{~m} \mathrm{a}^{-1}$, a depth to time conversion yields power peaks at $\geqslant 3.5 \mathrm{a},<3.5$ to $<0.35 \mathrm{a}$, and $\leqslant 0.35 \mathrm{a}$.

Power peaks with periodicity $\geqslant 3.5$ a $(\geqslant 3.22 \mathrm{~m})$ are displayed by all time-(depth-) series. These events cannot, however, be precisely constrained with the sample number and length of record available in this study. Power at $\geqslant 3.5 \mathrm{a}$ is both a product of the length of the time-series used in this study and of "real" trends in the data. The latter was tested by increasing the number of lags examined in the spectral study. The presence of power in the multi-annual period suggests that collection of longer time-series, $i$.e. deeper cores, may yield valuable information concerning events with periodicities $\geqslant 3.5 \mathrm{a}$.

Power peaks with periodicity $\leqslant 0.35$ a $(\leqslant 0.35 \mathrm{~m})$ are displayed by several time-series. However, events represented by power in this periodicity are almost indistinguishable from noise and thus at the sampling interval used in this study further resolution of these events is not statistically justifiable.

Assuming an average net mass balance for the core of $0.92 \mathrm{~m} \mathrm{a}^{-1}$ and an error in sample position of 
$\pm 0.16 \mathrm{~m}$ events with periodicities of $0.92 \pm 0.15 \mathrm{~m}$ and $0.46 \pm 0.16 \mathrm{~m}$ are annual and subannual, respectively. All time-series sets display power in the subannual period while only chloride, reactive phosphate, microparticles in the size range $<0.50$ to $0.63 \mu \mathrm{m}$, and reactive silicate display significant power peaks in the annual range.

\section{Non-periodic events}

Since spectral analysis provides a view of the periodic elements in a time-series assemblage this technique yields a smoothed display of the data. Nonperiodic components of the time-series sets, although comprising a small portion of the record in this study, need to be examined on an individual basis. The most apparent non-periodic anomaly in concentration is found at the depth 3.0 to $3.5 \mathrm{~m}$. It is displayed by density, debris bands, and the time-series for chloride, sodium, reactive iron, reactive silicate, reactive phosphate, ammonium, and microparticles in the range 0.50 to $0.80 \mu \mathrm{m}$ and 3.17 to $10.00 \mu \mathrm{m}$ as relatively high values. The presence of a major density transition at this depth suggests that densification and/or ablation may exert some control on the distribution of concentrations down core. Alternatively, relatively high concentrations of chemical species may imply deposition during a period of intensified atmospheric circulation. The lack of spectral power in the annual period for the density time-series and the general non-synchroneity of the spectral signature (Fig. 2c) of this time-series with others in this study suggests that trends in the density time-series are not associated with trends in the chemical species and/or microparticle time-series.

Notably although several of the chemical timeseries record annual and subannual events, the number of debris bands encountered down core does not match the total $\beta$-activity of the core. The presence of debris bands is therefore not usable as a stratigraphic marker but rather as an indication of events such as unusual ablation and/or intensified transport of debris to the core site.

\section{Sources}

Chemical and physical constituents in the core are introduced from several source types, size source areas, and distances. Source input timing and atmospheric circulation interpretations, where appropriate, for the chemical and physical constituents analyzed are discussed in the following order: chloride, sodium, reactive iron, reactive silicate, reactive phosphate, ammonium, $\mathrm{pH}$, microparticles, $\delta \mathrm{D}$, and $\delta(180)$. Volcanism although a potential source for several of the preceding has been deleted from the discussion that follows since it is unlikely as a periodically occurring source at the study site.

The primary source for the chloride in this core is marine and the closest marine source to Nun Kun during the period of the summer monsoon is the Arabian Sea, a distance of $\approx 1250 \mathrm{~km}$ from the core site. Values of chloride from fresh surface snows analyzed at several sites in the Nun Kun area (Mayewski and others, 1983) compared to those of fresh ran samples collected $75 \mathrm{~km}$ down-wind from Nun Kun at Gulmarg (Sequeira and Keilkar, 1978), suggest progressive depletion of chloride as air travels off the Arabian Sea to the core site (Mayewski and others, 1983). The annual power peak derived from the spectral analysis of the chloride time-series is larger than the subannual peak which is consistent with the view that the major input of chloride comes once each year. Since concentrations of chloride in fresh suminer snow (Mayewski and others, 1983) are very similar to those representing annual pulses in the time-series record, the high core values are assumed to be summer events. Subannual input of chloride probably results from the inflow of oceanic air which to a varying degree enters this site throughout the year from sources more distant than the Arabian Sea.

Sodium is brought to the core site either in com- bination with chloride from a sea-salt source or independently from crustal weathering. Since sodium has a higher mean concentration than chloride it probably comes from an admixture of these sources. Sodium has a relatively strong subannual spectral power peak and a weak annual peak. Crustal weathering would be a source from any wind direction and, therefore, any season thus explaining the stronger peak in the subannual period.

The primary source for periodically occurring reactive iron and reactive silicate is crustal weathering. Reactive iron has the higher mean concentration and a dominant subannual power peak suggesting perhaps a more local and/or larger source. Annual power in the reactive silicate spectral signature is less prominent than subannual power suggesting that annual inputs of this species come from a source that is limited or long-travelled by comparison with the subannual input or inputs of reactive iron. Subannual input of the reactive silicate may come from the same local weathering source as the reactive iron while the annual reactive silicate pulse may be separate. Measurements of reactive iron and reactive silicate on fresh summer snow from Nun Kun (Mayewski and others, 1983) suggest that these species are derived, in general, from a relatively low-elevation air mass directed off either the Indian subcontinent or the Tibetan Plateau.

Reactive phosphate has potentially both biogenic and anthropogenic sources, and for this study displays spectral power in both the annual and subannual ranges. Examination of temporal and spatial distributions measured in this study of reactive phosphate reveal: (1) that several of the high reactive phosphate values in the time-series correspond with debris band positions while the mean reactive phosphate value of samples having no visible debris bands is lower than that of rain from remote northern hemispheric areas $<0.06 \mu \mathrm{M}$ (Graham and Duce, 1979) and (2) similarities in distribution of reactive phosphate and reactive iron concentrations in fresh summer snow collected from several elevations on Nun Kun (Mayewski and others, 1983). The foregoing are suggestive of phosphate influx due to adsorption onto wind-blown materials such as iron oxide coatings as might be expected from an agricultural site where exposed terrain has been subjected to fertilizer usage (Mayewski and others, 1983). Aerosol loading from eroded soil material is a notable component of the atmosphere in north-west India (Bryson and Swain, 1981). Since summer reactive phosphate concentrations, determined from the fresh snow study (Mayewski and others, 1983) are similar to the maximum values displayed in the reactive phosphate time-series the annual power peak probably represents summer input. While transport of wind-blown material may be a likely source for summer inputs of reactive phospate, subannual inputs may also be derived from this source as well as biogenic emissions and fuel-burning (Davidson and others, 1981).

Ammonium present in the core samples has as its most probable sources in this area anthropogenic and biogenic activity. The ammonium time-series display the same relative power in both the annual and subannual period as might be expected considering potential multiple sources and multiple timing of inputs. No unique sources can be defined and thus this species may not be useful as a stratigraphic marker. However, analysis of ammonium from freshly fallen summer snow collected in the study area reveals that the relatively high values, $>0.5 \mu \mathrm{M}$, are found at elevations below $5300 \mathrm{~m}$ (Mayewski and others, 1983). Examination of Nepalese aerosols by Ikegami and others (1980) reveals a similar distribution in ammonium concentration with ammonium sulfate particles at elevations $<3000 \mathrm{~m}$ and sulfate particles at $>5000 \mathrm{~m}$.

$\mathrm{pH}$ has similar spectral power in both annual and subannual period which is probably indicative of the fact that it is a composite measure of strong acids (i.e. nitric and sulfuric) and weak acids (i.e. carbonic) from multiple sources. While $\mathrm{pH}$ measurements 
on fresh summer snow from Nun Kun in conjunction with other measurements have been used to help differentiate air masses (Mayewski and others, 1983) their use as a climate reconstruction tool in areas such as the Himalaya is suspect not only because of potential multiple sources but also because a number of workers (Scholander and others, 1961; Berner and others, 1978 Stauffer and Berner, 1978; Oeschger and others, 1982) have shown that even polar ice and snow are easily "contaminated" with $\mathrm{CO}_{2}$.

The fifteen size grades of microparticles measured as part of this study display a regular decrease in concentration per size grade as expected from Junge (1963, p. 111-201). This relationship indicates that sorting in transport and source area exert control on the microparticle distributions measured in this study. Microparticle sources are not only varied but they can be additive and include, as summarized by E.M. Thompson (1980), chemical reactions (natural and anthropogenic) and incorporation of volcanic, extraterrestrial, terrestrial, and marine components.

Junge (1963, p. 111-201) divides microparticles up into: Aitken $(<0.1 \mu \mathrm{m})$, large $(0.1$ to $1.0 \mu \mathrm{m})$, and giant $(>1.0 \mu \mathrm{m})$ sizes. Preservation of this grouping was investigated for the microparticle size grades in this study as a first approximation prior to interpretation of the data. The microparticle size grades used in this study, $<0.50$ to $12.70 \mu \mathrm{m}$, do not provide sufficient detail to differentiate Junge's (1963) finer grade, Aitken size particles, but they are divisible by comparison of their spectral properties into three size-grade groups (Fig. $2 a$ and b) $:<0.50$ to $0.80 \mu \mathrm{m}, 0.80$ to $2.00 \mu \mathrm{m}$, and 2.00 to $12.70 \mu \mathrm{m}$. This division roughly spans Junge's (1963) large and giant range with an intermediate "gray" group at 0.80 to $2.00 \mu \mathrm{m}$. The $<0.50$ to $0.80 \mu \mathrm{m}$ microparticle size group displays power in both annual and subannual periods (Fig. 2a) while the 0.80 to $2.00 \mu \mathrm{m}$ group has a spectral signature in which power in the subannual period dominates over power in the annual period (Fig. $2 \mathrm{a})$. The 2.00 to $12.70 \mu \mathrm{m}$ group displays power in the subannual period but none in the annual period (Fig. 2c).

As noted by Lamb (1970) and Shaw (1979), microparticles $\leqslant 1.00 \mu \mathrm{m}$ are believed to have long residence times in the stratosphere and/or high troposphere. Residence time, transport distance, and potential multiple sources for these microparticles prevents determination of unique source types and/or source areas. Although no elemental analysis of the microparticles in our study was undertaken, such studies at South Pole (E.M. Thompson, 1980) reveal that a large portion of these microparticles contain iron and silicate. This is substantiated in our study by the similarity in spectral signatures of the timeseries for reactive silicate and the $<0.50$ to $0.80 \mu \mathrm{m}$ size grade of microparticles.

The 2.00 to $12.70 \mu \mathrm{m}$ microparticle size group is probably derived from a more local source than the 0.50 to $0.80 \mu \mathrm{m}$ group based purely on size. The sitespecific local derivation of the 2.00 to $12.70 \mu \mathrm{m}$ microparticles is further substantiated by their high concentration in the Nun Kun area relative to concentrations of microparticles in other high-altitude alpine areas such as Mt Kenya (L.G. Thompson, [1981] and Quelccaya, Peru (Thompson and others, 1979).

Values of $\delta D$ were measured regularly every $0.16 \mathrm{~m}$ down core whereas $\delta(180)$ was only measured at selected depths. To test $\delta D$ to $\delta(180)$ relationships down-core values and a suite of fresh summer snowfall samples collected in the elevation range 5130 to $5512 \mathrm{~m}$ (Mayewski and others, 1983) were examined. Best-fit linear regressions for $\delta D$ and $\delta(180)$ down-hole and surface samples are $\delta D=7.1 \delta(180)+5.2$ and $\delta D=8.1 \times$ $\delta(180)+13.4$, respectively. By comparison the best fit for northern hemisphere continental stations is $\delta D=8.0 \delta(180)+10$ (Dansgaard, 1964) and for suites of samples relatively close to Nun Kun in the central Hindu Kush and Garhwals $\delta D=8.1 \delta(180)+12$ and $\delta D=$ $8.0 \delta(180)+10$, respectively (Niewodniczañski and others, 1981). Although it should be noted that the surface and down-hole samples in our study come from different elevations, comparison of these with fits from Dansgaard (1964) and Niewodniczański and others (1981) suggest that our down-hole samples may have experienced some degree of post-depositional alteration perhaps due to slight diffusion and/or melting. Although post-depositional alteration may have had some effect on the distribution down core of $\delta D$ values it has not affected the distribution of other chemical species and the microparticles. Glaciochemical analysis of a core collected from a low elevation Norwegian glacier (Davies and others, 1982) reveals that ions migrate down core by order of solubility. The coincidence down core of reactive iron, reactive silicate, and microparticles all of low solubility, with higher solubility chloride, reactive phosphate, and ammonium suggests that post-depositional alteration by melting and/or diffusion if present is minimal at the core site.

Spectral power for the $\delta D$ values is apparent for the subannual period but not annually even though monsoonal circulation in the area results in major shifts in the temperature of the air masses entering this site. The study of the fresh surface snow reveals why a major annual $\delta D$ power peak may not exist since it can be used to demonstrate that during any single event two adjacent air masses may have quite different temperatures and thus individual storm events may be as effective as seasonal air mass shifts in creating $\delta D$ distributions.

\section{Synchroneity of selected time-series sets}

Time-dependent relationships between two timeseries sets can be expressed using cross-spectral analysis in terms of phase shift and the strength of their dependence at various frequencies (Edwards and Thornes, 1973). Coherence between base and cross sets as close to unity as possible are sought although knowledge of the zero level of significance for coherence values (Koopmans, 1974) provides information concerning the reliability of coherence values less than unity. Phase shift (lead or lag) of selected timeseries sets that are useful as annual and/or suhannual indicators in this study, and that display power at statistically similar periods are examined (Table II). Since air mass circulation in the Himalaya is complicated, it cannot be assumed that all timeseries sites with annual or subannual spectral power necessarily enter the core site simultaneously. However, several examples of time-series sets which do enter simulataneously are dealt with below.

Phase shift for the chemical-species time series chloride, sodium, and reactive phosphate (Table II) suggest that all three species enter the core site in-phase annually. Since the annual pulse of high chloride concentration enters the core site in summer, the cross-spectral analysis demonstrates that the annual power peaks of sodium and reactive phosphate correspond to summer events.

Phase shift for examples of the spectrally defined groups equivalent to Junge's (1963) large and giant microparticles are also presents (Table II). Based on their cross-spectral relationships the large and giant particles enter the core site in phase subannually.

\section{SUMMARY AND DISCUSSION}

Analysis of selected chemical properties (chloride, sodium, reactive iron, reactive silicate, reactive phosphate, $\delta D, \delta(180)$, total $\beta$-activity, and $\mathrm{pH}$ ) and physical properties (density, debris band and ice lens locations, and microparticles in 15 size grades from 0.50 to $12.70 \mu \mathrm{m}$ ) reveal details concerning the net mass balance, timing of precipitation events and source of precipitation for a core collected at $4908 \mathrm{~m}$ on Sentik Glacier. The core is believed to have experienced minimal post-depositional alter- 
TABLE II. CROSS-SPECTRAL RELATIONSHIPS FOR SELECTED TIME-SERIES SETS

\begin{tabular}{|c|c|c|c|c|c|c|}
\hline $\begin{array}{l}\text { Base } \\
\text { set }\end{array}$ & $\begin{array}{c}\text { Cross } \\
\text { set }\end{array}$ & $\underset{m}{\text { Period }}$ & $\begin{array}{l}\text { Amplitude of } \\
\text { power peak }\end{array}$ & Coherence & $\begin{array}{l}\text { Zero significance } \\
\text { level for } \\
\text { coherence }\end{array}$ & $\begin{array}{c}\text { Phase } \\
m\end{array}$ \\
\hline $\begin{array}{l}\text { Chloride } \\
\text { Chloride }\end{array}$ & $\begin{array}{l}\text { Sodium } \\
\text { Sodium }\end{array}$ & $\begin{array}{l}0.81 \\
1.08\end{array}$ & $\begin{array}{l}5.03 \\
5.92\end{array}$ & $\begin{array}{l}0.85 \\
0.86\end{array}$ & $\begin{array}{l}0.66 \\
0.66\end{array}$ & $\begin{array}{l}0.05 \\
1.00\end{array}\left(\begin{array}{l}0.01 \\
1.08\end{array}\right)$ \\
\hline Chloride & $\begin{array}{l}\text { Reactive } \\
\text { Phosphate }\end{array}$ & 0.81 & 1.73 & 0.70 & 0.44 & $0.91 \quad(0.74)$ \\
\hline Chloride & $\begin{array}{l}\text { Reactive } \\
\text { Phosphate }\end{array}$ & 1.08 & 1.70 & 0.70 & 0.44 & $0.91 \quad(0.99)$ \\
\hline $\begin{array}{l}0.50 \text { to } \\
0.63 \mu \mathrm{m} \\
\text { Micro- } \\
\text { particles }\end{array}$ & $\begin{array}{l}0.63 \text { to } \\
0.80 \mu \mathrm{m} \\
\text { Micro- } \\
\text { particles }\end{array}$ & 0.45 & $40 \times 10^{6}$ & 0.87 & 0.66 & $0.99(0.45)$ \\
\hline $\begin{array}{l}0.63 \text { to } \\
8.00 \mu \mathrm{m} \\
\text { Micro- } \\
\text { particles }\end{array}$ & $\begin{array}{l}8.00 \text { to } \\
10.00 \mu \mathrm{m} \\
\text { Micro- } \\
\text { particles }\end{array}$ & 0.45 & 23.90 & 0.98 & 0.66 & $1.00(0.45)$ \\
\hline $\begin{aligned} 1 & -0.81 \text { and } \\
2 & - \\
\text { chemical } & (\mu \mathrm{m})^{2} / \mathrm{cy} \\
3 & \text { - from Koop } \\
4 & \text { - in fract }\end{aligned}$ & $\begin{array}{l}1.08 \text { m are } \\
\text { species in } \\
m^{-1} \text {. } \\
\text { pmans (1974) } \\
\text { ions of a ci }\end{array}$ & $\begin{array}{l}\text { used to span } \\
(\mu M)^{2} / \text { cy m-1 } \\
\text { at } 90 \% \text { conf } i\end{array}$ & $\begin{array}{l}\text { I the annual pe } \\
\text {; micropartic } \\
\text { fidence level. }\end{array}$ & $\begin{array}{l}\text { eriod. } \\
\text { cles in }\end{array}$ & & \\
\hline
\end{tabular}

ation and thus to be a true monitor of the combined wet and dry deposition reaching this site.

Based on a total $\beta$-activity core chronology the $16.6 \mathrm{~m}$ core represents an $\approx 17 \pm 0.3$ year record. The average net mass balance computed from this chronology is $0.92 \mathrm{~m} \mathrm{a}^{-1}$ which using an average core density of $570 \mathrm{~kg} \mathrm{~m}^{-3}$ is $0.62 \mathrm{~m} \mathrm{a}^{-1}$ water equivalent. The latter value is somewhat less than the precipitation rate of $0.90 \mathrm{~m} \mathrm{a}^{-1}$ water equivalent estimated for the valley bottom adjacent to the core site (Qazi, 1973) suggesting a decrease in precipitation with elevation in this area.

Spectral analysis of chemical and physical timeseries sets developed from the core reveal recognizable periodic events at $\leqslant 0.32 \mathrm{~m}$ (noise), $<3.22$ to $>0.32 \mathrm{~m}$, and $\geqslant 3.22 \mathrm{~m}$. The periodicity $<3.22$ to $>0.32 \mathrm{~m}$ includes annual and subannual events. The existence of spectrally defined periodic events is of particular significance in this study since they help to prove that selected high-altitude temperate glaciers in the Himalaya can provide stratigraphic records for use in the delineation of former climate. Discussion of these periodic events and the source and atmospheric circulation implications of the chemical and physical time-series are summarized below.

Chloride concentrations are highest in the summer and are derived at this time from a marine source, the Arabian Sea. Subannual chloride inputs probably come from more distant marine sources. Sodium covaries with chloride since much of it is marine-derived. However, some sodium is probably brought into the core site from crustal weathering during both the summer and winter monsoon events. Reactive phosphate is probably carried to the core site during the summer adsorbed onto wind-blown materials derived from exposed agricultural sites. Subannual inputs of this species may come from combined biologic and anthropogenic sources. Ammonium has multiple sources which are not differentiable in this study. Reactive iron and reactive silicate are both derived from crustal weathering and are deposited at the core site during at least the summer and winter monsoons and silicate comes to the core site from either a distinct limited source or over a long distance annually. $\mathrm{pH}$ distribution with time may be a composite monitor of strong and weak acid contributions to the site and interpre- tation of its distribution down core may be too complicated to allow development of a useful record. Microparticles have multiple sources and are spectrally divisible into two major groups with a "gray" intermediate group. The smallest particles, $<0.50$ to $0.80 \mu \mathrm{m}$, have a strong annual input and a weaker subannual input, are believed to be long-travelled and derived from a relatively high-altitude air mass and composed of at least silicate. Microparticle size grades 2.00 to $12.70 \mu \mathrm{m}$ are probably of more local derivation than the $<0.50$ to $0.80 \mu \mathrm{m}$ group. $\delta D$ displays a weak subannual periodicity either due to dampening by melting and/or diffusion or because temperature differences season to season are no greater than those found during subseasonal events.

Multiannual periodicity is displayed by all timeseries. Events with periodicity $\geqslant 3.5$ years require far more investigation because of their potential value to monsoon studies. This information could be gained by deeper drilling.

\section{ACKNOWLEDGEMENTS}

Members of the 1980 Nun Kun Expedition included P.A. Mayewski (leader), W.B. Lyons, P. Axelson, $P$.A. Jeschke, and $J$. Sevigny of the University of New Hampshire, N. Ahmad, M.N. Kaul, and K. Kahn of Aligarh Muslim University, India, and P.T. Davis of Mount Holyoke College. We would like to thank Ghulam Ali and the people of Tongul, Ladakh, for all of their help in this project. Ted Loder (University of New Hampshire) gave invaluable advice concerning our chemical studies. Isotope analyses were graciously provided by J. Jouzel and L. Merlivat (Saclay, France) and C. Lorius (Grenoble, France) and we are deeply indebted. L.G. Thompson (Ohio State University) very kindly provided all of the microparticle analyses. $J$. Borkland and P. Vornberger assisted in the preparation of the statistical analyses and $\mathbb{N}$. Pettigrew and M. Foster provided helpful insight into statistical interpretations. Critical reviews of the manuscript were provided by C. Lorius, R.M. Koerner, and L.G. Thompson. This study is part of a joint U.S. Indian study of Himalayan glaciers funded by U.S. National Science Foundation grant INT8U-03175. A permit for this study was provided by the Government of 
India and their cooperation and help in this program is very much appreciated.

\section{REFERENCES}

Berner, W.B., and others. 1978. Past atmospheric composition and climate: gas parameters measured on ice cores, by W.B. Berner, B. Stauffer, and H. Oeschger. Nature, Vol. 276, No. 5683, p. 53-55. Boucher, K. 1975. Global climate. New York, John Wiley and Sons, Inc.

Bryson, R.A., and Swain, M. 1981. Holocene variations of monsoonal rainfall in Rajasthan. Quaternary Research, Vol. 16, No. 2, p. 135-45.

Dansgaard, W. 1964 . Stable isotopes in precipitation. Tellus, Vol. 16, No. 4, p. 436-68.

Davidson, C.I., and others. 1981. Airborne lead and other elements derived from local fires in the Himalayas, by C.I. Davidson, T.C. Grimm, and M.A. Nasta. Science, Vol. 214 , No. 4527, p. 1344-46.

Davies, T.D., and others. 1982. Preferential elution of strong acid from a Norwegian ice cap, by T.D. Davies, C.E. Vincent, and P. Brimblecombe. Nature, Vol . 300, No. 5888, p. 161-63.

Edwards, A.M.C., and Thornes, J.B. 1973. Annual cycle in river water quality: a time-series approach. Water Resources Research, Vol. 19, No. 5, p. 1286-95.

Glibert, P.M., and Loder, T. 1977. Automated analysis of nutrients in sea water: a manual of techniques. Woods Hole Technical Report 77-47.

Graham, W.F., and Duce, R.A. 1979. Atmospheric pathway, of the phosphorus cycle. Geochimica et Cosmochimica Acta, Vol. 43, No. 8, p. 1185-1208.

Hahn, D.G., and Shukla, J. 1976. An apparent relationship between Eurasian snow cover and Indian monsoon rainfall. Journal of the Atmospheric Sciences, Vol. 33, No. 12, p. 2461-62.

Hastenrath, S. 1978. Heat-budget measurements on the Quelccaya ice cap, Peruvian Andes. Journal of Glaciology, Vol. 20, No. 82, p. 85-97.

Ikegami, K., and others. 1980. Preliminary report on the vertical distribution of aerosol particles over the Nepal Himalayas, by K. Ikegami, J. Inoue, K. Higuchi, and A. Ono. Seppyō, Vol. 42, Special Issue, p. 86-89.

Junge, C.E. 1963. Air chemistry and radioactivity. New York, Academic Press.

Koopmans, L.H. 1974. The spectral analysis of timeseries. New York, Academic Press. (Probability and Mathematical Statistics, 22.)

Lamb, H.H. 1970. Volcanic dust in the atmosphere, with a chronology and assessment of its meteorological significance. Philosophical Transactions of the Royal Society of London, Ser. A, Vol. 266, No. 1178, p. 425-533.

Mayewski, P.A., and Jeschke, P.A. 1979. Himalayan and trans-Himalayan glacier fluctuations since AD 1812. Arctic and Alpine Research, Vol. 11, No. 3, p. 26787 .

Mayewski, P.A., and others. 1981. Reconnaissance glacio-chemical studies in the Indian Himalayas, by P.A. Mayewski, W.B. Lyons, and N. Ahmad. Proceedings of the Eastern Snow Conference, 38th annual meeting, p. 45-48.

Mayewski,P.A., and others. 1983. Chemical composition of a high altitude fresh snowfall in the Ladakh Himalayas, by P.A. Mayewski, W.B. Lyons, and N. Ahmad. Geophysical Research Letters, Vol. 10, No. 1, p. 105-08.
Mukherjee, B.K., and others. 1981. High-level temperatures and winds over tropics and Indian summer monsoon, by B.K. Mukherjee, R.S. Reddy, and Bh. V. Ramana Murty. Journal of Geophysical Research, Vol. 86, No. C10, p. 9688-92.

Niewodniczañski, J., and others. 1981. The altitude effect on the isotopic composition of snow in high mountains, by J. Niewodniczañski, J. Grabczak, L. Barañski, and J. Rzepka. Journal of Glaciology, Vol. 27, No. 95, p. 99-111.

veschger, $\mathrm{H}_{\text {., }}$ and others. 1982 . Atmospheric $\mathrm{CO}_{2}$ content in the past deduced from ice-core analyses, by H. Oeschger, B. Stauffer, A. Neftel, J. Schwander, and R. Zumbrunn. Annals of Glaciology, Vol. 3 , p. 227-32.

Qazi, N.A. 1973. Water resources development in suru Basin (Ladakh). Srinagar, Vacant Press.

Rangarajan, C., and Eapen, C.D. 1981. Estimates of interhemispheric transport of radioactive debris by the East African low-level jet stream. Journal of Geophysical Research, Vol. 86, No. C12, p. 12153-54.

Reiter, E.R. 1981. The Tibet connection. Natural History, Vol. 90, No. 1, p. 64-71.

Scholander, P.F., and others. 1961. Composition of gas bubbles in Greenland icebergs, by P.F. Scholander, E.A. Hemmingsen, L.K. Coachman, and D.C. Nutt. Journal of Glaciology, Vol. 3, No. 29, p. 813-22.

Sequeira R., and Keilkar, D. 1978. Geochemical implications of summer monsoonal rainwater composition over India. Journal of Applied Meteorology, Vol. 17, No. 9, p. 1390-96.

Shaw, G.E. 1979. Considerations on the origin and properties of the Antarctic aerosol. Reviews of Geophysics and Space Physics, Vol. 17, No. 8, p. $1983-98$.

Stauffer, B., and Berner, W. 1978. $\mathrm{CO}_{2}$ in natural ice. Journal of Glaciology, Vol. 21, No. 85, p. 291-300.

Stookey, L.L. 1970. Ferrozine - a new spectrophotometric reactant from iron. Analytical Chemistry, Vol. 42, No. 7, p. 778-881.

Thompson, E.M. 1980. 911 years of microparticle deposition at the South Pole: a climatic interpretation. Ohio State University. Institute of Polar Studies. Report No. 73.

Thompson, L.G. 1977. Microparticles, ice sheets and climates. Ohio State University. Institute of Polar Studies. Report No. 64 .

Thompson, L.G. [1981.] Ice core studies from Mt Kenya, Africa, and their relationships to other tropical ice core studies. [Union Géodésique et Géophysique Internationale. Association Internationale des Sciences Hydrologiques.] Sea level, ice, and climatic change. Proceedings of the symposium held 7-8 December 1979 during the 17 th general assembly of the International Union of Geodesy and Geophysics, Canberra, p. 55-62. (IAHS Publication No. 131.)

Thompson, L.G., and others. 1979. Climatic ice core records from the tropical Quelccaya ice cap, by L.G. Thompson, S. Hastenrath, and B. Morales Arnao. Science, Vol. 203, No. 4386, p. 1240-43.

Wissmann, $H$, von. 1960. Die heutige Vergletscherung und Schneegrenze in Hochasien, mit Hinweisen auf die Vergletscherung der letzten Eiszeit. Akadamie der Wissenschaften und der Literatur in Mainz. Abhandlungen der Mathematisch-naturwissenschaftZichen Klasse. Jahrg. 1959, Nr. 14, p. 1103-1407.

Zall, D.M., and others. 1956. Photometric determination of chloride in water, by D.M. Zall, D. Fisher, and M.D. Garner. Analytical Chemistry, Vol. 28, No. 11, p. 1665-68. 
APPENDIX A. DOWN-HOLE DATA SETS

$$
\begin{array}{ll}
\begin{array}{l}
\text { Symbot } \\
\text { BETA }
\end{array} & \multicolumn{1}{c}{\text { Data set (units) }} \\
\begin{array}{l}
\text { DEBRIS AND ICE } \\
\text { BANDS }
\end{array} & \begin{array}{l}
\text { Debris bands }(2=\text { diffuse; } 4=\text { semi } \\
\text { concentrated }) \text { and ice bands }(=1)
\end{array} \\
\text { DENSITY } & =\text { Density }\left(\times 10^{3} \mathrm{~kg} \mathrm{~m}^{-3}\right) \\
\text { CL } & =\text { Chloride }(\mu \mathrm{M}) ; \text { note scale change } \\
\text { NA } & =\text { Sodium }(\mu \mathrm{M}) ; \text { note scale change } \\
\text { FE } & =\text { Reactive iron ( } \mu \mathrm{M}) ; \text { note two scales } \\
\text { SI02 } & =\begin{array}{l}
\text { Reactive silicate }(\mu \mathrm{M}) ; \text { note two } \\
\text { scales }
\end{array}
\end{array}
$$

Po4

$\mathrm{NH} 4$

DELTA D

UELTA 018

$\mathrm{pH}$

$\underset{10^{3}}{\operatorname{MICRQ}}=0.63 \times$

$\underset{10^{2}}{\operatorname{MICRQ}}=1.25 \times$
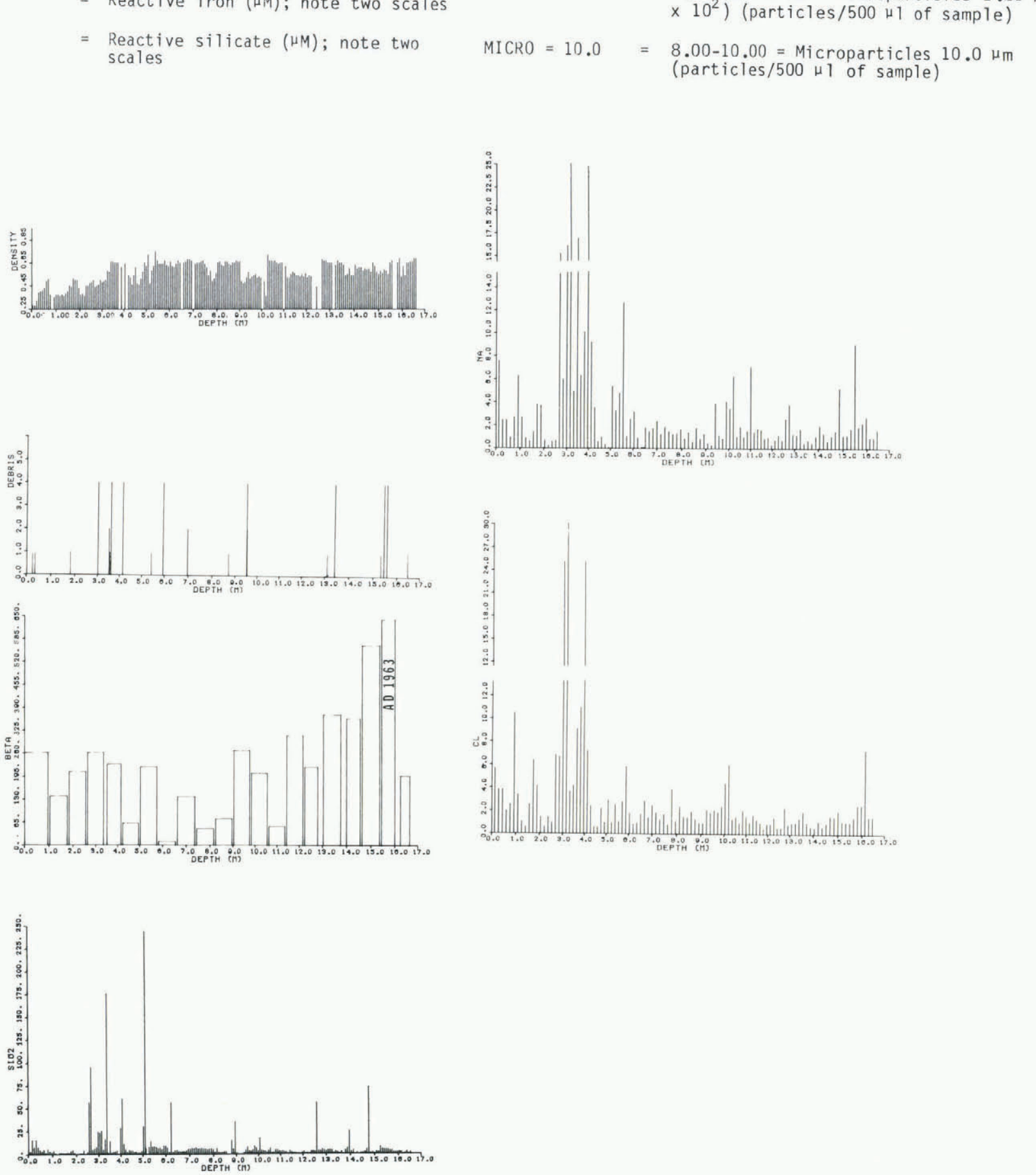

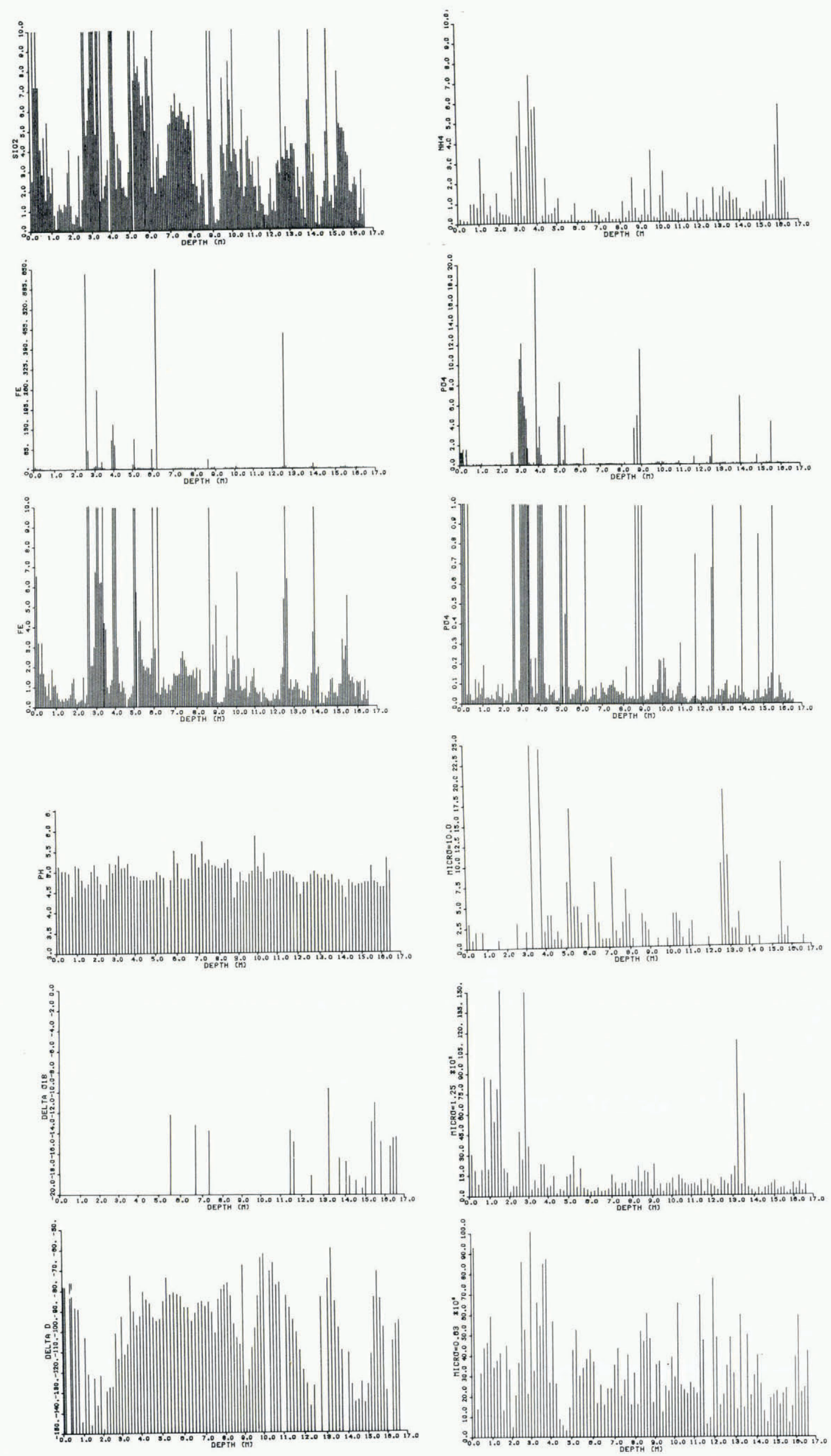

MS. received? April 1983 and in revised form 4 August 1983 